\title{
Drug therapies and presence of coronary artery disease may affect aortic stiffness in Alzheimer's disease
}

Osman Bektaș'

Zeki Yüksel Günaydın'

Ahmet Karagöz ${ }^{2}$

Ahmet Kaya'

'Ordu University, Department of Cardiology, Ordu, ${ }^{2}$ Giresun University, Department of Cardiology, Giresun, Turkey
Correspondence: Zeki Yüksel Günaydın Ordu University, Department of Cardiology, Ordu, Turkey 52100 Fax +904522239110

Email doktorzeki28@gmail.com
This article was published in the following Dove Press journal:

Clinical Interventions in Aging

13 February 2015

Number of times this article has been viewed

\section{Dear editor}

We have read the original research entitled "Altered diastolic function and aortic stiffness in Alzheimer's disease" by Çalık et al "which was published in the July 2014 issue of Clinical Interventions in Aging, with great interest. We would like to touch on some points about this article.

Firstly, when clinical and demographic characteristics were evaluated, it was stated that the study and control groups included eleven (37\%) and $14(58 \%)$ hypertensive $(P=0.14)$ and four $(13 \%)$ and four $(16 \%)$ diabetic $(P=0.77)$ patients, respectively. It is obvious that there was no significant difference between the two groups in terms of these diseases, which are likely to affect aortic stiffness. On the other hand, lack of an explanation about use of antihypertensive and antidiabetic medication is conspicuous. We suggest that use of antihypertensive and antidiabetic therapy should also be similar between the study and control groups since antihypertensive and antidiabetic drugs have already been shown to affect arterial stiffness to various degrees. Angiotensin-converting enzyme inhibitors have been shown to improve arterial compliance, ${ }^{2}$ and angiotensin receptor blockers are also likely to have effects similar to those of angiotensin-converting enzyme inhibitors. ${ }^{3}$ When compared with vasodilating drugs from other groups, beta-blockers have a weaker effect on arterial stiffness and central pulsatile hemodynamics. ${ }^{4} \mathrm{Calcium}$ channel blockers also lower pulse wave velocity and reduce wave reflections, ${ }^{5}$ although to a lesser extent than renin-angiotensin inhibitors. Further, diuretics seem to have no beneficial effect on pulsatile hemodynamics. ${ }^{6}$ On the other hand, in the diabetic population, glitazones and peroxisome proliferator-activated receptor gamma agonists have been shown to decrease arterial stiffness in addition to having favorable effects on insulin resistance and glycemic control. Although the study and control groups included similar proportions of hypertensive and diabetic patients, these studies show that aortic stiffness is affected by antihypertensive and antidiabetic treatment. Therefore, in our opinion, it is essential to report all medications used by patients. ${ }^{7,8}$

Secondly, the status of the patients with regard to lipid profile and statin use is also not mentioned in the study. The lipid profile of patients in the study and control groups and status of statin use are important and should be stated in the article, because statins (HMG-CoA reductase inhibitors) provide additional protective/beneficial (pleiotropic) effects on the cardiovascular system in addition to their basic action in reducing lowdensity lipoprotein cholesterol. Although conflicting reports exist, statins are thought to improve arterial stiffness directly. ${ }^{9}$ 
Lastly, the association between coronary atherosclerosis and aortic stiffness had already been well identified. ${ }^{10}$ Was distribution of the patients with coronary artery disease similar between the study and control groups? We hope the authors are willing to comment on these three issues.

\section{Disclosure}

The authors have no conflicts of interest in this communication.

\section{References}

1. Çalık AN, Özcan KS, Yüksel G, et al. Altered diastolic function and aortic stiffness in Alzheimer's disease. Clin Interv Aging. 2014;9: 1115-1121.

2. Shahin YY, Khan JA, Chetter I. Angiotensin converting enzyme inhibitors effect on arterial stiffness and wave reflections: a meta-analysis and meta-regression of randomised controlled trials. Atherosclerosis. 2012;221(1):18-33.

3. Mahmud A, Feely J. Favourable effects on arterial wave reflection and pulse pressure amplification of adding angiotensin II receptor blockade in resistant hypertension. J Hum Hypertens. 2000;14(9):541-546.
4. Mahmud A, Feely J. $\beta$-blockers reduce aortic stiffness in hypertension but nebivolol, not atenolol, reduces wave reflection. Am J Hypertens. 2008;21(6):663-667.

5. Hayoz D, Zappe DH, Meyer MAR, et al. Changes in aortic pulse wave velocity in hypertensive postmenopausal women: comparison between a calcium channel blocker vs angiotensin receptor blocker regimen. J Clin Hypertens. 2012;14(11):773-778.

6. Morgan T, Lauri J, Bertram D, et al. Effect of different antihypertensive drug classes on central aortic pressure. Am J Hypertens. 2004;17(2): $118-123$.

7. Harashima K, Hayashi J, Miwa T, et al. Long-term pioglitazone therapy improves arterial stiffness in patients with type 2 diabetes mellitus. Metabolism. 2009;58(6):739-745.

8. Yu J, Jin N, Wang G, et al. Peroxisome proliferator-activated receptor $\gamma$ agonist improves arterial stiffness in patients with type 2 diabetes mellitus and coronary artery disease. Metabolism. 2007;56(10):1396-1401.

9. Rizos EC, Agouridis AP, Elisaf MS. The effect of statin therapy on arterial stiffness by measuring pulse wave velocity: asystematic review. Curr Vasc Pharmacol. 2010;8(5):638-644.

10. Van Popele NM, Mattace-Raso FU, Vliegenthart R, et al. Aortic stiffness is associated with atherosclerosis of the coronary arteries in older adults: the Rotterdam Study. J Hypertens. 2006;24(12):2371-2376. 


\title{
Authors' response
}

\author{
Ali Nazmi Çalık ${ }^{3}$ \\ Kazım Serhan Özcan ${ }^{4}$ \\ Gülbün Yüksel² \\ Barıș Güngör ${ }^{\prime}$ \\ Emre Aruğarslan' \\ Figen Varlıbaș ${ }^{2}$ \\ Ahmet Ekmekçi \\ Damirbek Osmonov' \\ Adem Tatlısu' \\ Mehmet Karaca' \\ Osman Bolca' \\ İzzet Erdinler'
}

'Department of Cardiology, Siyami Ersek Cardiovascular and Thoracic Surgery Center, Istanbul, ${ }^{2}$ Department of Neurology, Haydarpașa Numune Training and Research Hospital, Istanbul,

${ }^{3}$ Department of Cardiology, Yozgat State Hospital, Yozgat,

${ }^{4}$ Department of Cardiology, Derince Training and Research

Hospital, Kocaeli, Turkey

Correspondence: Ali Nazmi Çalık

Department of Cardiology, Yozgat State Hospital, Tașköprü Mahallesi, Hastane Caddesi, Merkez, 66100 Yozgat, Turkey

Tel +905059200344

Fax +9021 65613837

Email calik_nazmi@hotmail.com

\section{Dear editor}

First we want to thank Bektaş et al for their comments about our study. As mentioned in our paper, the patient and control groups were matched in terms of having diabetes mellitus, hypertension, and systolic blood pressure levels. However, antihypertensive and antidiabetic drugs may affect aortic stiffness and this may be a limitation of our study.

\section{Disclosure}

The authors have no conflicts of interest in this communication.

\section{Publish your work in this journal}

Clinical Interventions in Aging is an international, peer-reviewed journal focusing on evidence-based reports on the value or lack thereof of treatments intended to prevent or delay the onset of maladaptive correlates of aging in human beings. This journal is indexed on PubMed Central, MedLine,
CAS, Scopus and the Elsevier Bibliographic databases. The manuscript management system is completely online and includes a very quick and fair peer-review system, which is all easy to use. Visit http://www.dovepress. $\mathrm{com} /$ testimonials.php to read real quotes from published authors. 